The $I J A$ is a peer-reviewed open-access, electronic journal, freely available without charge to users

Produced by the AquacultureHub non-profit Foundation Sale of $I J A$ papers is strictly forbidden

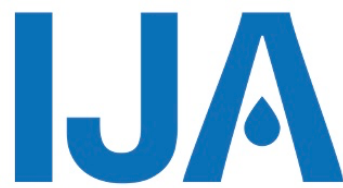

\title{
Effects of taurine levels in feed on blood biochemical parameters and antioxidant indexes of Cynoglossus semilaevis and their responses to fishing stress
}

\section{Xueliang Sun ${ }^{1 \#}$, Hong Yu1 ${ }^{\#}$, Kezhi Xing ${ }^{1}$, Yunchen Tian ${ }^{2 *}$, Chengxun Chen ${ }^{1}$, Yongjun Guo ${ }^{1}$, Hui Shi ${ }^{1}$, Shuyuan Yang ${ }^{3}$, Shuqi Chen ${ }^{4}$, Qingkui Wang ${ }^{1 *}$}

1 Tianjin Key Laboratory of Aqua-ecology and Aquaculture, College of Fisheries, Tianjin Agricultural University, 22 Jinjing Road, 300384 Tianjin, China

${ }^{2}$ College of Computer and Information Engineering, Tianjin Agricultural University, 22 Jinjing Road, 300384 Tianjin, China

3 Yangliuqing Agriculture Service Center, In Xiqing Area of Tianjin City, Tianjin 300380, China

${ }^{4}$ Tianjin Lida Sea Water Resources Development Co., Ltd. Tianjin 300380, China

Keywords: Cynoglossus semilaevis; Taurine level; Biochemistry; Physiology; Antioxidant; capture; stress

\begin{abstract}
Cynoglossus semilaevis blood biochemical parameters and antioxidant indexes that respond to fishing stress were measured under the influence of different feed taurine levels. With taurine levels of $0 \%, 0.5 \%, 1 \%$ and $1.5 \%, 4$ groups of test feeds were prepared. After 28 days of feeding. Serum was collected before stress and at $0,4,12$, $24,48,96 \mathrm{~h}$ after stress to determine the content of total protein, cholesterol, GPT, GOT, nitric oxide, lysozyme, blood sugar and the activity of glutathione (GSH-PX), superoxide dismutase (SOD), malondialdehyde (MDA) and antioxidant capacity (AOC), the results show: Feeding a feed with a taurine content of $0.5 \%$ has a better inhibitory effect on cholesterol and GOT in Cynoglossus semilaevis after fishing stress, and has obvious antistress effect on lysozyme and protein. The $0.5 \%$ group had the lowest MDA content $12 \mathrm{~h}$ after fishing stress. The results suggested that feeding the feed with a taurine content of $0.5 \%$, the Cynoglossus semilaevis blood biochemical parameters and antioxidant indexes to fishing stress has a better response.
\end{abstract}

\footnotetext{
* Corresponding authors: E-mail address: 37918538@qq.com; \#These authors contributed equally to this work
} 


\section{Introduction}

The Cynoglossus semilaevis is a near-shore warm-water fish species with a small population in the world. The Cynoglossus semilaevis has strong growth ability and many unsaturated fatty acids. The artificial breeding of Cynoglossus semilaevis has been a long time, However, because the physiology and biology of the semi-smooth tongue sole is different from other fish, the commercial reproduction technology is not mature, In particular, there is no special feed for Cynoglossus semilaevis.

Taurine, a special sulfonic acid, is an essential amino acid distributed in animals and plants. Taurine is a new type of feed additive, which has a positive effect on fish feeding organs and can promote fish body growth. The studied that the effect of taurine on fish nutrition and fish feed (Wang et al., 2013).

Environmental stress is the stress caused by the environment on the survival state of fish, which is divided into acute stress and chronic stress. In the process of fish farming, various related stress factors will trigger the body to respond to the stress response. As a common acute stress, fishing stress has been studied by many people.

In summary, this study took the Cynoglossus semilaevis.as the research object, to study the effects of different taurine content on the biochemical and antioxidant indexes of Cynoglossus semilaevis in various periods of fishing stress. The purpose is to investigate the response of different taurine levels in feed to the blood biochemical indexes and antioxidant indexes of Cynoglossus semilaevis to fishing stress. To provide reference and basis for reducing the unnatural consumption of Cynoglossus semilaevis during fishing stress and feed configuration of Cynoglossus semilaevis.

\section{Experimental fish and experimental feed}

\section{Materials and Methods}

The Cynoglossus semilaevis is artificially cultivated. They are all taken from Tianjin Haisheng Aquaculture Co., Ltd., and the average weight of individuals with Cynoglossus semilaevis is $45.12 \pm 0.37 \mathrm{~g}$. The breeding experiments are carried out in Tianjin Haisheng Aquaculture Co., Ltd. In the pool, 12 blue plastic boxes (size $0.78 \times 0.57 \times 0.46 \mathrm{~m}^{3}$ ) are placed and divided into 4 concentration gradient test groups. We had 4 boxes in each group, 30 fish in each box, and a breeding cycle is 28 days.

Table 1 Formula and nutrition level of experimental feed (\%)

\begin{tabular}{ccccc}
\hline & 1 & 2 & 3 & 4 \\
\hline Fish meal & 46 & 46 & 46 & 15 \\
Casein & 15 & 15 & 15 & 15 \\
Soybean meal & 15 & 15 & 10 & 10 \\
Fish oil & 10 & 10 & 5 & 5 \\
Starch & 5 & 5 & 3 & 3 \\
Yeast & 3 & 3 & 3 & 3 \\
Minerals & 3 & 3 & 1 & 1 \\
Vitamin & 2 & 1.5 & 1 & 100 \\
Adhesive & 1 & 1 & 100 & 5 \\
Taurine & 0 & 0.5 & & 14.5 \\
Combined & 100 & 100 & 52.45 & 9.15 \\
nutrients & & 52.40 & 14.34 & \\
Crude protein & 52.39 & 14.10 & 9.03 & \\
Crude fat & 14.00 & 8.99 & &
\end{tabular}


Note: Each $\mathrm{kg}$ of premix contains vitamins: vitamin A 900000IU, vitamin D 200000IU, vitamin E $4500 \mathrm{mg}$, vitamin K3 220mg, vitamin B1 320mg, vitamin B2 1090mg, vitamin B5 $2000 \mathrm{mg}$, vitamin B6 500mg, vitamin B12 $1.6 \mathrm{mg}$, vitamin C 5000mg, pantotoic acid $1000 \mathrm{mg}$, folate $165 \mathrm{mg}$, choline $60000 \mathrm{mg}$. Minerals in the premix per $\mathrm{kg}: 2.0 \mathrm{~g}$ copper sulfate, $25 \mathrm{~g}$ iron sulfate, $22 \mathrm{~g}$ zinc sulfate, $7 \mathrm{~g}$ manganese sulfate, $0.04 \mathrm{~g}$ sodium selenite, $0.026 \mathrm{~g}$ potassium iodide and $0.1 \mathrm{~g}$ cobalt chloride.

The random unit group design method in the single factor experimental design used in this experiment, the taurine content in fish feed is influencing factor and 4 groups are prepared with taurine content of $0 \%, 0.5 \%, 1.0 \%$ and $1.5 \%$. Test feeds are recorded as $\mathrm{A} 1, \mathrm{~A} 2, \mathrm{~A} 3$ and A4. The preparation method of the feed is as shown in Table $\mathbf{1}$. The raw materials are ground and mixed to prepare granules, after drying the pellets that put them in the refrigerator for storage.

\section{Feeding and management}

According to the traditional test method of Cynoglossus semilaevis feeding, Before the breeding, the pool should be disinfected, and the dissolved potassium permanganate is splashed in the pool. After 7 days, put new water in the pool and the aeration $2 \mathrm{~d}$. Before the test starts, the experimental fish are cultured with basic feed for 7 days. Change water twice after feeding every day. New water that it should be aerated for 24 $h$, inject about $1 / 3$ of new water, keep aeration, maintain dissolved oxygen content is 8$10 \mathrm{mg} / \mathrm{L}$, water temperature is $21-22{ }^{\circ} \mathrm{C}$. The salt is $29-32$, the $\mathrm{pH}$ is $7.8-8.0$, the ammonia nitrogen is $<0.15 \mathrm{mg} / \mathrm{l}$, and the nitrite nitrogen is $<0.05 \mathrm{mg} / \mathrm{l}$. Adjust the light intensity with an ordinary incandescent lamp to maintain even light. Four sets of Cynoglossus semilaevis were fed with the above four test feeds, and fed twice a day at 8 am and $4 \mathrm{pm}$, respectively. The daily feeding amount is $1 \%-3 \%$ of the fish body weight. The feeding condition of the Cynoglossus semilaevis is observed. After the fish is feeding for 30 minutes, the remaining feed is removed to avoid damaging the water quality. The breeding period is 28 days.

\section{Experimental drugs and reagents}

The total protein (TP) assay kit (with standard: Coomassie Brilliant Blue method). The anion on the Coomassie Brilliant Blue dye combines with the protein - $\mathrm{NH} 3+$ to make the solution turn blue. The protein content can be calculated by measuring the absorbance.

The cholesterol (T-CHO) determination kit (COD-PAP method) is purchased by Nanjing Jiancheng Bioengineering Research Institute; The color of the quinone compound produced after the sample reaction is proportional to the content of cholesterol. The absorbance values of the calibration standard tube and the sample tube are measured respectively to calculate the cholesterol content.

The alanine aminotransferase (GPT) assay kit (Lai's method) was purchased by Nanjing Jiancheng Bioengineering Research Institute; Alanine aminotransferase can catalyze alanine and ketoglutarate to produce glutamate and pyruvate. Under acidic conditions, pyruvate can be condensed with 2,4-dinitrophenylhydrazine to form pyruvate dinitrophenylhydrazone. Under alkaline conditions, it appears orange-red, the color depth is in accordance with Beer's law, and there is a maximum absorption at $520 \mathrm{~nm}$.

The aspartate aminotransferase (GOT) determination kit (Lai's method) was purchased by Nanjing Jiancheng Bioengineering Research Institute; GOT catalyzes the transamination reaction between ketone and aspartic acid to generate glutamic acid and oxaloacetic acid. Oxaloacetic acid further decarboxylates to generate acid; it can react with 2,4-dihydrazine to generate 2,4-dihydrazone. It shows brown-red under alkaline conditions: measure the change of absorbance at $505 \mathrm{~nm}$, and then calculate the GOT enzyme activity.

Nitric oxide (NO) cartridge (nitrate reductase method) purchased by Nanjing Institute of Bioengineering; This method uses nitrate reductase to specifically reduce $\mathrm{NO}^{3}$ to $\mathrm{NO}^{2}$ , and the concentration is determined by the color depth. 
The lysozyme detection kit (turbidimetry) was purchased by Nanjing Jiancheng Bioengineering Research Institute; In a certain concentration of turbid bacterial liquid, because lysozyme can hydrolyze the peptidoglycan on the bacterial cell wall to lyse the bacteria, the concentration decreases and the light transmittance is enhanced, so the content of lysozyme can be estimated based on the change of light transmittance.

Glucose determination kit (glucose oxidase-peroxidase method) purchased by Shanghai Rongsheng Biological Pharmaceutical Co., Ltd.; Glucose produces gluconic acid and hydrogen peroxide under the action of glucose oxidase. Under the action of peroxidase, hydrogen peroxide makes o-tolidine produce a blue substance, which is proportional to the concentration of glucose at a wavelength of $625 \mathrm{~nm}$. The glucose content in the sample can be calculated by measuring the absorbance of the blue substance.

Malondialdehyde (MDA) assay kit (TBA method) (Cat. No.: A003-1) purchased by Nanjing Institute of Bioengineering, anhydrous ethanol, glacial acetic acid, 1,1,3,3tetraethoxypropane; Malondialdehyde (MDA) detection kit (TBA method) uses a color reaction based on the reaction of MDA and thiobarbituric acid (TBA) to produce a red product to form a red MDA-TBA adduct. The MDA-TBA adduct has a maximum absorption at $535 \mathrm{~nm}$, which can be detected by colorimetry.

Total Antioxidant Capacity (T-AOC) Test Box (Colorimetric Method) (Cat. No. A015) purchased by Nanjing Jiancheng Bioengineering Research Institute;

Total superoxide dismutase (T-SOD) assay kit (using hydroxylamine method) (A0011) prepared by Nanjing Institute of Bioengineering, glacial acetic acid, riboflavin;

Glutathione Peroxidase (GSH-PX) Assay Box (A005) purchased by Nanjing Jiancheng Bioengineering Research Institute;

Petroleum ether, $0.85 \%$ physiological saline, distilled water, absolute ethanol, and the like.

\section{Test methods}

Sample collection

The test was performed with a Cynoglossus semilaevis at the beginning and end of the weighing and weighing period. After the test, the fish were fasted for $24 \mathrm{~h}$, and the weight of the fish before and after feeding was recorded.

At the beginning of the fishing stress, the water depth in the culture tank was quickly reduced from the original $35 \mathrm{~cm}$ to $25 \mathrm{~cm}$. Then the test fish was chased to the side of the box with a small net and repeated fishing. The process lasted for $20 \mathrm{~min}$ and the water was kept. After the stress, the water depth recovered. Up to $35 \mathrm{~cm}$. Samples were taken at $0,4,12,24,48$, and $96 \mathrm{~h}$ before the start of the fishing stress and at the same time, and 4 fish were randomly taken from each box. The needle was inserted into the tail vein at the lateral line of the fish's anal fin position. The needle was placed in a centrifuge tube, placed in a centrifuge, centrifuged at $1500 \mathrm{r} / \mathrm{min}$, centrifuged for $30 \mathrm{~min}$, and the supernatant was taken and placed in $a-80{ }^{\circ} \mathrm{C}$ and saved for testing.

\section{Sample determination}

Determination of blood index of Cynoglossus semilaevis

Total protein, cholesterol, GPT, GOT, nitric oxide, lysozyme, total superoxide dismutase activity (T-SOD), malondialdehyde content (MDA), total was measured using a reagent assay kit provided by Nanjing Jiancheng Engineering Research Institute. Antioxidant capacity level (T-AOC), glutathione peroxidase activity (GSH-PX) and reagent assay kit provided by Shanghai Rongsheng Biopharmaceutical Co., Ltd. detect blood sugar.

\section{Data Processing and Statistical Analysis}

All data were analyzed and processed using Excel and SPSS 19.0. Use Excel software to initially organize the data and create a table of each indicator. One-Way ANOVA was performed on the data with SPSS19.0, and the difference between the groups was 
analyzed by Duncan's multiple comparison. The significant level was determined as $\mathrm{P}<0.05$. Test data are expressed as mean \pm standard error (Mean $\pm \mathrm{SE}$ ).

\section{Results}

Effects of different taurine levels on total protein of Cynoglossus semilaevis

It can be seen from Table 2 that the total protein content in the $0 \%$ group was significantly lower than that in the $0.5 \%, 1 \%$, and $1.5 \%$ groups at $12 \mathrm{~h}$ after the fishing stress $(P<0.05)$, and the differences were not significant at other time points $(P>0.05)$. In the $0 \%$ group, the total protein level was significantly increased at $4 \mathrm{~h}$ after fishing stress $(P<0.05)$; the total protein level at $12 \mathrm{~h}$ after fishing stress was significantly lower than that before stress $(P<0.05)$. In the $1.5 \%$ group that the total protein level was significantly higher than that at $48 \mathrm{~h}$ after the stress $(P<0.05)$. There was no significant difference in total protein levels at other time points $(P>0.05)$. There was no significant difference in total protein levels between the $0.5 \%$ and $1 \%$ groups $(P<0.05)$.

Table 2 Effects of different taurine levels on total protein of Cynoglossus semilaevis: $\mathrm{g} / \mathrm{L}$

\begin{tabular}{lllll} 
& $0 \%$ & $0.5 \%$ & $1 \%$ & $1.5 \%$ \\
\hline Before & $0.36 \pm 0.06^{\mathrm{ABa}}$ & $0.40 \pm 0.24^{\mathrm{Aa}}$ & $0.44 \pm 0.29^{\mathrm{Aa}}$ & $0.41 \pm 0.07^{\mathrm{ABa}}$ \\
Oh & $0.38 \pm 0.06^{\mathrm{ABa}}$ & $0.52 \pm 0.13^{\mathrm{Aa}}$ & $0.36 \pm 0.11^{\mathrm{Aa}}$ & $0.37 \pm 0.03^{\mathrm{ABa}}$ \\
$4 \mathrm{~h}$ & $0.45 \pm 0.04^{\mathrm{Ba}}$ & $0.38 \pm 0.05^{\mathrm{Aa}}$ & $0.48 \pm 0.17^{\mathrm{Aa}}$ & $0.36 \pm 0.03^{\mathrm{ABa}}$ \\
$12 \mathrm{~h}$ & $0.29 \pm 0.03^{\mathrm{Aa}}$ & $0.50 \pm 0.03^{\mathrm{Ab}}$ & $0.43 \pm 0.13^{\mathrm{Ab}}$ & $0.44 \pm 0.02^{\mathrm{Bb}}$ \\
$24 \mathrm{~h}$ & $0.35 \pm 0.05^{\mathrm{ABa}}$ & $0.47 \pm 0.08^{\mathrm{Aa}}$ & $0.42 \pm 0.09^{\mathrm{Aa}}$ & $0.38 \pm 0.08^{\mathrm{ABa}}$ \\
$48 \mathrm{~h}$ & $0.33 \pm 0.10^{\mathrm{ABa}}$ & $0.49 \pm 0.11^{\mathrm{Aa}}$ & $0.43 \pm 0.17^{\mathrm{Aa}}$ & $0.27 \pm 0.15^{\mathrm{Aa}}$ \\
$96 \mathrm{~h}$ & $0.41 \pm 0.12^{\mathrm{ABa}}$ & $0.39 \pm 0.17^{\mathrm{Aa}}$ & $0.42 \pm 0.15^{\mathrm{Aa}}$ & $0.38 \pm 0.05^{\mathrm{ABa}}$ \\
\hline
\end{tabular}

Note: Different uppercase letters in the table indicate that the same group has significant difference between different time points $(P<0.05)$, and different lowercase letters indicate significant difference between different groups at the same time point $(P<0.05)$.

Effects of different taurine levels on cholesterol in Cynoglossus semilaevis

It can be seen from Table 3 that the cholesterol level in the $1 \%$ group was the highest at $12 \mathrm{~h}$ after the fishing stress, which was significantly higher than $0 \%, 0.5 \%$, and $1.5 \%(P<0.05)$. The difference was not significant at other time points $(P>0.05)$. The cholesterol level decreased significantly at $12 \mathrm{~h}$ and $96 \mathrm{~h}$ after the fishing stress, which was lower than the cholesterol levels at other time points $(P<0.05)$. The cholesterol levels were significantly higher at $24 \mathrm{~h}$ after the fishing stress, and was than those at other time points $(P<0.05)$. In the $0.5 \%$ group, cholesterol levels were significantly lower than those at other time points at $4 \mathrm{~h}$ after stress $(P<0.05)$. 
Table 3 Effects of different taurine levels on cholesterol in Cynoglossus semilaevis: $\mathrm{mmol} / \mathrm{L}$

\begin{tabular}{lllll}
\hline & $0 \%$ & $0.5 \%$ & $1 \%$ & $1.5 \%$ \\
\hline Before & $1.24 \pm 0.21^{\mathrm{ABa}}$ & $1.01 \pm 0.25^{\mathrm{Aa}}$ & $1.51 \pm 0.34^{\mathrm{Aa}}$ & $1.09 \pm 0.43^{\mathrm{ABa}}$ \\
Oh & $1.50 \pm 0.87^{\mathrm{ABa}}$ & $1.31 \pm 0.43^{\mathrm{Aa}}$ & $0.91 \pm 0.56^{\mathrm{Aa}}$ & $1.09 \pm 0.18^{\mathrm{ABa}}$ \\
$4 \mathrm{~h}$ & $1.03 \pm 0.38^{\mathrm{ABa}}$ & $0.91 \pm 0.42^{\mathrm{Aa}}$ & $0.77 \pm 0.17^{\mathrm{Aa}}$ & $0.85 \pm 0.52^{\mathrm{Aa}}$ \\
$12 \mathrm{~h}$ & $0.79 \pm 0.51^{\mathrm{Aa}}$ & $0.69 \pm 0.37^{\mathrm{ABab}}$ & $1.51 \pm 0.18^{\mathrm{Ab}}$ & $1.97 \pm 0.13^{\mathrm{ABab}}$ \\
$24 \mathrm{~h}$ & $1.79 \pm 0.57^{\mathrm{Ba}}$ & $0.98 \pm 0.36^{\mathrm{Aa}}$ & $1.52 \pm 0.62^{\mathrm{Aa}}$ & $2.07 \pm 1.13^{\mathrm{Ba}}$ \\
$48 \mathrm{~h}$ & $1.35 \pm 0.10^{\mathrm{ABa}}$ & $1.11 \pm 0.21^{\mathrm{Aa}}$ & $1.00 \pm 0.79^{\mathrm{Aa}}$ & $0.75 \pm 0.47^{\mathrm{Aa}}$ \\
$96 \mathrm{~h}$ & $0.64 \pm 0.41^{\mathrm{Aa}}$ & $1.10 \pm 0.42^{\mathrm{Aa}}$ & $1.51 \pm 0.87^{\mathrm{Aa}}$ & $1.68 \pm 0.22^{\mathrm{ABa}}$ \\
\hline
\end{tabular}

Note: Different uppercase letters in the table indicate that the same group has significant difference between different time points $(P<0.05)$, and different lowercase letters indicate significant difference between different groups at the same time point $(P<0.05)$.

Effects of different taurine levels on alanine aminotransferase in the Cynoglossus semilaevis

It can be seen from Table 4 that at $12 \mathrm{~h}$ after the fishing stress, the GPT level in the $1 \%$ group was significantly higher than that in the other groups $(P<0.05)$, the GPT level in the $0 \%$ group was significantly increased $4 \mathrm{~h}$ after the stress $(P<0.05)$, the level of GPT decreased significantly at $24 \mathrm{~h}$ and $48 \mathrm{~h}$ after stress, which was lower than that at other time points $(P<0.05)$. In the $0.5 \%$ group, the GPT level was significantly increased at $4 \mathrm{~h}$ after stress $(\mathrm{P}<0.05)$. The GPT level at $48 \mathrm{~h}$ after stress was significantly lower than that at other time points $(P<0.05)$.

Table 4 Effects of different taurine levels on alanine aminotransferase in the Cynoglossus semilaevis: $\mathrm{U} / \mathrm{g}$

\begin{tabular}{lllll}
\hline & $0 \%$ & $0.5 \%$ & $1 \%$ & $1.5 \%$ \\
\hline before & $33.04 \pm 12.55^{\mathrm{ABa}}$ & $34.19 \pm 36.42^{\mathrm{ABa}}$ & $24.71 \pm 3.23^{\mathrm{ABa}}$ & $19.06 \pm 12.30^{\mathrm{Aa}}$ \\
Oh & $32.53 \pm 23.28^{\mathrm{ABa}}$ & $19.94 \pm 9.71^{\mathrm{ABa}}$ & $23.50 \pm 10.48^{\mathrm{ABa}}$ & $22.14 \pm 20.51^{\mathrm{Aa}}$ \\
$4 \mathrm{~h}$ & $40.95 \pm 21.16^{\mathrm{Ba}}$ & $37.86 \pm 41.65^{\mathrm{Ba}}$ & $29.62 \pm 14.03^{\mathrm{ABa}}$ & $31.19 \pm 49.52^{\mathrm{Aa}}$ \\
$12 \mathrm{~h}$ & $34.65 \pm 17.34^{\mathrm{ABab}}$ & $40.18 \pm 15.48^{\mathrm{ABab}}$ & $48.54 \pm 11.00^{\mathrm{Bb}}$ & $14.81 \pm 14.43^{\mathrm{Aa}}$ \\
$24 \mathrm{~h}$ & $30.42 \pm 12.67^{\mathrm{ABa}}$ & $32.40 \pm 23.52^{\mathrm{ABa}}$ & $24.92 \pm 17.55^{\mathrm{ABa}}$ & $22.59 \pm 13.14^{\mathrm{Aa}}$ \\
$48 \mathrm{~h}$ & $16.17 \pm 11.41^{\mathrm{Aa}}$ & $11.04 \pm 3.45^{\mathrm{Aa}}$ & $30.27 \pm 26.47^{\mathrm{ABa}}$ & $33.00 \pm 19.06^{\mathrm{Aa}}$ \\
$96 \mathrm{~h}$ & $36.86 \pm 35.30^{\mathrm{ABa}}$ & $44.47 \pm 18.80^{\mathrm{ABa}}$ & $37.68 \pm 36.37^{\mathrm{ABa}}$ & $31.79 \pm 28.18^{\mathrm{Aa}}$ \\
\hline Note & & & & \\
\hline
\end{tabular}

Note: Different uppercase letters in the table indicate that the same group has significant difference between different time points $(P<0.05)$, and different lowercase letters indicate significant difference between different groups at the same time point $(P<0.05)$.

Effects of different taurine levels on transaminase of Asparagus in Cynoglossus semilaevis

It can be seen from Table 5 that the GOT level was highest in the $0.5 \%$ group before the fishing stress, and was significantly higher than the $0 \%, 1 \%$, and $1.5 \%$ groups $(\mathrm{P}<0.05)$; The GOT level in the $0 \%$ group at $12 \mathrm{~h}$ after the fishing stress significantly higher than $0.5 \%, 1 \%, 1.5 \%$ group $(\mathrm{P}<0.05)$, the GOT level of $1.5 \%$ group was significantly lower than $0 \%, 0.5 \%, 1 \%$ group $(P<0.05)$. In the $0 \%$ group, the GOT level 
significantly increased at $12 \mathrm{~h}$ after stress, which was higher than the GOT levels at other time points $(P<0.05)$. In the $0.5 \%$ group, the GOT level significantly decreased at $96 \mathrm{~h}$ after fishing stress, while the other time points were not significantly different $(P<0.05)$. In the $1.5 \%$ group, the GOT level was significantly higher than that at other time points $(P<0.05)$ at $4 \mathrm{~h}$ after fishing stress; at $12 \mathrm{~h}$ and $24 \mathrm{~h}$ after fishing stress, the GOT level was significantly decreased $(P<0.05)$.

Table 5 Effects of different taurine levels on transaminase of Asparagus in Cynoglossus semilaevis: $\underline{\mathrm{U} / \mathrm{g}}$

\begin{tabular}{lllll}
\hline & $0 \%$ & $0.5 \%$ & $1 \%$ & $1.5 \%$ \\
\hline Before & $60.61 \pm 5.74^{\mathrm{Aa}}$ & $53.80 \pm 12.95^{\mathrm{ABa}}$ & $59.42 \pm 22.64^{\mathrm{ABa}}$ & $52.23 \pm 33.17^{\mathrm{ABa}}$ \\
0h & $78.70 \pm 44.43^{\mathrm{Aa}}$ & $58.62 \pm 37.50^{\mathrm{ABa}}$ & $64.09 \pm 46.22^{\mathrm{ABa}}$ & $39.00 \pm 29.10^{\mathrm{ABa}}$ \\
$4 \mathrm{~h}$ & $81.62 \pm 9.18^{\mathrm{Aa}}$ & $60.68 \pm 47.00^{\mathrm{ABa}}$ & $87.55 \pm 13.04^{\mathrm{Ba}}$ & $88.66 \pm 19.03^{\mathrm{Ba}}$ \\
$12 \mathrm{~h}$ & $98.81 \pm 11.44^{\mathrm{BC}}$ & $65.51 \pm 31.77^{\mathrm{ABb}}$ & $44.73 \pm 33.98^{\mathrm{ABab}}$ & $16.00 \pm 14.45^{\mathrm{Aa}}$ \\
$24 \mathrm{~h}$ & $63.18 \pm 24.90^{\mathrm{Aa}}$ & $54.50 \pm 45.30^{\mathrm{ABa}}$ & $55.33 \pm 33.65^{\mathrm{ABa}}$ & $9.01 \pm 7.67^{\mathrm{Aa}}$ \\
$48 \mathrm{~h}$ & $40.64 \pm 7.42^{\mathrm{Aa}}$ & $44.11 \pm 32.68^{\mathrm{ABa}}$ & $16.73 \pm 15.68^{\mathrm{Aa}}$ & $53.74 \pm 36.54^{\mathrm{ABa}}$ \\
& & & & \\
$96 \mathrm{~h}$ & $22.34 \pm 15.34^{\mathrm{Aa}}$ & $20.74 \pm 18.38^{\mathrm{Aa}}$ & $37.62 \pm 20.64^{\mathrm{ABa}}$ & $41.45 \pm 31.77^{\mathrm{ABa}}$ \\
\hline
\end{tabular}

Note: in the table, different capital letters mean significant difference between different groups at different time points $(P<0.05)$, while different lowercase letters mean significant difference between different groups at the same time point $(P<0.05)$.

Effects of different taurine levels on nitric oxide in the Cynoglossus semilaevis

It can be seen from Table 6 that the content of nitric oxide in the $0 \%$ group was significantly higher than $0.5 \%, 1 \%$, and $1.5 \%(\mathrm{P}<0.05)$ at $24 \mathrm{~h}$ after the fishing stress, and the other three groups were not significantly different $(P>0.05)$. In the $0 \%$ group, the level of nitric oxide was significantly decreased at $12 \mathrm{~h}$ after fishing stress $(P<0.05)$, and the level of nitric oxide was significantly increased at $96 \mathrm{~h}$ after fishing stress $(P<0.05)$. In the $1 \%$ group, the level of nitric oxide was significantly increased at $48 \mathrm{~h}$ and $96 \mathrm{~h}$ after fishing stress $(\mathrm{P}<0.05)$. In the $1.5 \%$ group, the level of nitric oxide was significantly increased at $48 \mathrm{~h}$ and $96 \mathrm{~h}$ after fishing stress $(\mathrm{P}<0.05)$. 
Table 6 Effects of different taurine levels on nitric oxide in the Cynoglossus semilaevis: $\mu \mathrm{mol} / \mathrm{L}$

\begin{tabular}{|c|c|c|c|c|}
\hline & $0 \%$ & $0.5 \%$ & $1 \%$ & $1.5 \%$ \\
\hline Before & $158.22 \pm 4.87^{\mathrm{ABbC}}$ & $62.13 \pm 18.79^{A a}$ & $143.22 \pm 42.07^{\mathrm{ABab}}$ & $143.98 \pm 84.72^{A C}$ \\
\hline Oh & $152.87 \pm 20.75^{\mathrm{ABa}}$ & $144.60 \pm 43.75^{\mathrm{ABa}}$ & $114.25 \pm 46.20^{\mathrm{ABa}}$ & $142.76 \pm 55.56^{\mathrm{Aa}}$ \\
\hline $4 h$ & $108.28 \pm 16.78^{\mathrm{Aa}}$ & $102.29 \pm 16.57^{A a}$ & $141.83 \pm 41.10^{\mathrm{ABa}}$ & $100.91 \pm 29.55^{\mathrm{Aa}}$ \\
\hline $12 \mathrm{~h}$ & $100.91 \pm 40.03^{\mathrm{Aa}}$ & $94.48 \pm 101.10^{\mathrm{Aa}}$ & $65.97 \pm 37.88^{\mathrm{ABa}}$ & $142.75 \pm 29.87^{\mathrm{Aa}}$ \\
\hline $24 h$ & $257.70 \pm 35.55^{\mathrm{BCb}}$ & $115.63 \pm 21.11^{\mathrm{ABa}}$ & $119.31 \pm 57.60^{\mathrm{ABa}}$ & $134.48 \pm 28.80^{\mathrm{Aa}}$ \\
\hline $48 \mathrm{~h}$ & $254.94 \pm 127.34^{\mathrm{BCa}}$ & $201.60 \pm 39.14^{\mathrm{BCa}}$ & $204.82 \pm 99.33^{\mathrm{BCa}}$ & $202.98 \pm 106.54^{\mathrm{ABa}}$ \\
\hline $96 h$ & $282.98 \pm 68.83^{\mathrm{Ca}}$ & $253.56 \pm 36.63^{\mathrm{Ca}}$ & $300.91 \pm 88.21^{\mathrm{Ca}}$ & $303.67 \pm 54.66^{\mathrm{Ba}}$ \\
\hline
\end{tabular}

Note: in the table, different capital letters mean significant difference between different groups at different time points $(P<0.05)$, while different lowercase letters mean significant difference between different groups at the same time point $(P<0.05)$.

Effects of different taurine levels on lysozyme of the Cynoglossus semilaevis

It can be seen from Table 7 that the lysozyme content in the 1.5\% group was the highest at the $0 \mathrm{~h}$ of the fishing stress, and was significantly higher than that in the $0 \%$, $0.5 \%$, and $1 \%$ groups $(\mathrm{P}<0.05)$. The lysozyme content in the $1.5 \%$ group was significantly higher than $0 \%, 0.5 \%, 1 \%$ group at $4 \mathrm{~h}$ after the fishing stress $(\mathrm{P}<0.05)$; The $1 \%$ group lysozyme content was significantly higher than $0 \%, 0.5 \%, 1.5 \%$ group at $24 \mathrm{~h}$ after fishing stress, $(\mathrm{P}<0.05)$; The $0 \%$ group of lysozyme levels was significantly decreased $(\mathrm{P}<0.05)$ at $4 \mathrm{~h}$ after fishing stress. The $0.5 \%$ group and the $0 \%$ group have the same trend.

Table 7 Effects of different taurine levels on lysozyme of the Cynoglossus semilaevis: $\mu \mathrm{g} / \mathrm{ml}$

\begin{tabular}{lllll}
\hline & $0 \%$ & $0.5 \%$ & $1 \%$ & $1.5 \%$ \\
\hline Before & $2.44 \pm 0.53^{\mathrm{ABa}}$ & $2.46 \pm 0.35^{\mathrm{BCa}}$ & $3.15 \pm 0.14^{\mathrm{Da}}$ & $3.27 \pm 0.13^{\mathrm{Ba}}$ \\
Oh & $2.42 \pm 0.31^{\mathrm{ABa}}$ & $2.76 \pm 0.15^{\mathrm{BCab}}$ & $2.80 \pm 0.09^{\mathrm{Cab}}$ & $2.97 \pm 0.13^{\mathrm{ABb}}$ \\
$4 \mathrm{~h}$ & $1.45 \pm 0.26^{\mathrm{Aa}}$ & $1.21 \pm 0.26^{\mathrm{Aa}}$ & $1.69 \pm 0.04^{\mathrm{Aa}}$ & $2.39 \pm 0.13^{\mathrm{Ab}}$ \\
$12 \mathrm{~h}$ & $2.51 \pm 1.50^{\mathrm{ABa}}$ & $2.40 \pm 0.45^{\mathrm{BCa}}$ & $2.39 \pm 0.13^{\mathrm{Ba}}$ & $2.95 \pm 0.49^{\mathrm{ABa}}$ \\
$24 \mathrm{~h}$ & $3.28 \pm 0.16^{\mathrm{ABb}}$ & $2.35 \pm 0.31^{\mathrm{BCa}}$ & $3.09 \pm 0.28^{\mathrm{CDb}}$ & $3.28 \pm 0.55^{\mathrm{Bb}}$ \\
$48 \mathrm{~h}$ & $2.32 \pm 0.31^{\mathrm{ABab}}$ & $2.54 \pm 0.64^{\mathrm{BCa}}$ & $3.47 \pm 0.04^{\mathrm{Eb}}$ & $3.29 \pm 0.09^{\mathrm{Bab}}$ \\
$96 \mathrm{~h}$ & $2.49 \pm 0.09^{\mathrm{ABb}}$ & $2.52 \pm 0.01^{\mathrm{BCb}}$ & $3.50 \pm 0.03^{\mathrm{Eb}}$ & $3.30 \pm 0.05^{\mathrm{Ba}}$ \\
\hline
\end{tabular}

Note: in the table, different capital letters mean significant difference between different groups at different time points $(P<0.05)$, while different lowercase letters mean significant difference between different groups at the same time point $(P<0.05)$.

Effects of different taurine levels on glucose in Cynoglossus semilaevis

It can be seen from Table 8 that before the fishing stress, the blood glucose level in the $1.5 \%$ group was significantly higher than that in the $0 \%, 0.5 \%$, and $1 \%$ groups $(P<0.05)$, and there was no significant difference in each group at other time points $(P>0.05)$. The blood glucose levels of $0.5 \%$, and $1 \%$ groups had significantly higher at 0 $h$ after fishing stress, and was than those in each group $(P<0.05)$, and significantly 
decreased at $96 \mathrm{~h}$ after fishing stress $(P<0.05)$. In the $0.5 \%$ group, the blood glucose concentration was significantly increased $48 \mathrm{~h}$ after fishing stress $(\mathrm{P}<0.05)$, and the blood glucose concentration was significantly higher than other groups that before fishing stress and $0 \mathrm{~h}$ after fishing stress. $(\mathrm{P}<0.05)$.

Table 8 Effects of different taurine levels on glucose in Cynoglossus semilaevis: $\mathrm{mmol} / \mathrm{L}$

\begin{tabular}{lllll}
\hline & $0 \%$ & $0.50 \%$ & $1 \%$ & $1.5 \%$ \\
\hline Before & $0.05 \pm 0.04^{\mathrm{Aa}}$ & $0.07 \pm 0.03^{\mathrm{Aa}}$ & $0.05 \pm 0.01^{\mathrm{Aa}}$ & $0.20 \pm 0.01^{\mathrm{Ab}}$ \\
Oh & $0.23 \pm 0.05^{\mathrm{BCa}}$ & $0.14 \pm 0.02^{\mathrm{ABa}}$ & $0.20 \pm 0.06^{\mathrm{Ba}}$ & $0.22 \pm 0.06^{\mathrm{Aa}}$ \\
$4 \mathrm{~h}$ & $0.21 \pm 0.16^{\mathrm{BCa}}$ & $0.17 \pm 0.03^{\mathrm{ABa}}$ & $0.23 \pm 0.10^{\mathrm{Ba}}$ & $0.17 \pm 0.03^{\mathrm{Aa}}$ \\
$12 \mathrm{~h}$ & $0.14 \pm 0.05^{\mathrm{ABa}}$ & $0.18 \pm 0.05^{\mathrm{ABa}}$ & $0.20 \pm 0.05^{\mathrm{Ba}}$ & $0.18 \pm 0.04^{\mathrm{Aa}}$ \\
$24 \mathrm{~h}$ & $0.25 \pm 0.04^{\mathrm{BCa}}$ & $0.18 \pm 0.03^{\mathrm{ABa}}$ & $0.18 \pm 0.05^{\mathrm{Ba}}$ & $0.21 \pm 0.04^{\mathrm{Aa}}$ \\
$48 \mathrm{~h}$ & $0.26 \pm 0.09^{\mathrm{Ca}}$ & $0.28 \pm 0.20^{\mathrm{Ba}}$ & $0.14 \pm 0.05^{\mathrm{Ba}}$ & $0.20 \pm 0.08^{\mathrm{Aa}}$ \\
$96 \mathrm{~h}$ & $0.18 \pm 0.04^{\mathrm{BCa}}$ & $0.19 \pm 0.04^{\mathrm{ABa}}$ & $0.19 \pm 0.05^{\mathrm{Ba}}$ & $0.18 \pm 0.09^{\mathrm{Aa}}$ \\
\hline
\end{tabular}

Note: in the table, different capital letters mean significant difference between different groups at different time points $(P<0.05)$, while different lowercase letters mean significant difference between different groups at the same time point $(P<0.05)$.

Effects of different taurine contents on glutathione peroxidase activity of the Cynoglossus semilaevis

It can be seen from Table 9 that the GSH activity of the $1.0 \%$ group was highest at $12 \mathrm{~h}$ after the fishing stress; the GSH activity of the 0\% group was the lowest at $96 \mathrm{~h}$ after the fishing stress; the $0 \%, 0.5 \%$ and $1 \%$ groups of the activity of GSH enzyme were began to decrease at $4 \mathrm{~h}$ after the fishing stress, while the $1 \%$ group showed a significant downward trend $12 \mathrm{~h}$ after the fishing stress; The GSH activity of the 4 groups remained at a similar level at $24 \mathrm{~h}$ after the fishing stress. With the increase of fishing stress time, the activity of GSH enzyme in each group showed was first increase and then decreased, and then gradually stabilized.

Table 9 Effects of different taurine contents on glutathione peroxidase activity of the Cynoglossus semilaevis: Vital Unit

\begin{tabular}{lllll}
\hline & $0 \%$ & $0.50 \%$ & $1 \%$ & $1.5 \%$ \\
\hline Before & $39.37 \pm 0.08^{\mathrm{Cc}}$ & $50.68 \pm 0.06^{\mathrm{Bb}}$ & $54.69 \pm 0.07^{\mathrm{Cb}}$ & $68.54 \pm 0.04^{\mathrm{Ba}}$ \\
Oh & $52.50 \pm 0.04^{\mathrm{Bb}}$ & $97.70 \pm 0.03^{\mathrm{Aa}}$ & $39.01 \pm 0.02^{\mathrm{Dc}}$ & $99.53 \pm 0.02^{\mathrm{Aa}}$ \\
$4 \mathrm{~h}$ & $86.04 \pm 0.05^{\mathrm{Aa}}$ & $57.60 \pm 0.03^{\mathrm{Bd}}$ & $73.28 \pm 0.05^{\mathrm{Bb}}$ & $65.99 \pm 0.03^{\mathrm{Bc}}$ \\
$12 \mathrm{~h}$ & $53.97 \pm 0.07^{\mathrm{Bb}}$ & $44.84 \pm 0.09^{\mathrm{Cc}}$ & $100.62 \pm 0.10^{\mathrm{Aa}}$ & $49.22 \pm 0.03^{\mathrm{Cc}}$ \\
$24 \mathrm{~h}$ & $25.52 \pm 0.02^{\mathrm{Dc}}$ & $33.90 \pm 0.01^{\mathrm{Da}}$ & $39.74 \pm 0.03^{\mathrm{Da}}$ & $29.17 \pm 0.07^{\mathrm{Eb}}$ \\
$48 \mathrm{~h}$ & $52.86 \pm 0.02^{\mathrm{Ba}}$ & $21.00 \pm 0.02^{\mathrm{Ec}}$ & $57.98 \pm 0.02^{\mathrm{Ca}}$ & $34.63 \pm 0.06 \mathrm{Db}$ \\
$96 \mathrm{~h}$ & $14.58 \pm 0.04^{\mathrm{Dc}}$ & $18.59 \pm 0.05^{\mathrm{Ec}}$ & $38.65 \pm 0.02^{\mathrm{Db}}$ & $44.11 \pm 0.05^{\mathrm{Ca}}$ \\
\hline
\end{tabular}

Note: in the table, different capital letters mean significant difference between different groups at different time points $(P<0.05)$, while different lowercase letters mean significant difference between different groups at the same time point $(P<0.05)$.

Effect of different taurine contents on SOD activity in serum of Cynoglossus semilaevis

It can be seen from Table $\mathbf{1 0}$ that in the $1.0 \%$ group, the activity of SOD was the lowest at $4 \mathrm{~h}$ after the fishing stress, and the decrease was larger. The activity of SOD was the highest in the $1 \%$ group at $96 \mathrm{~h}$ after the fishing stress. The 4 groups SOD activity was not significant difference between before the fishing stress and $0 \mathrm{~h}$ after the fishing stress. the activity of SOD recovered to the pre-stress level at $48 \mathrm{~h}$ after the 
fishing stress. In general, the SOD activity reached a high value at $96 \mathrm{~h}$ after the fishing stress, and the trend of SOD activity was first decreased and then increased.

Table 10 Effect of different taurine contents on SOD activity in serum of Cynoglossus semilaevis: $\mu \mathrm{mol} / \mathrm{g}$

\begin{tabular}{lllll}
\hline & $0 \%$ & $0.50 \%$ & $1 \%$ & $1.5 \%$ \\
\hline Before & $196.22 \pm 0.03^{\mathrm{Ba}}$ & $178.34 \pm 0.02^{\mathrm{Ca}}$ & $175.36 \pm 0.09^{\mathrm{Ba}}$ & $191.54 \pm 0.07^{\mathrm{Ba}}$ \\
Oh & $209.70 \pm 0.04^{\mathrm{ABa}}$ & $215.66 \pm 0.06^{\mathrm{ABa}}$ & $199.20 \pm 0.04^{\mathrm{Ba}}$ & $161.18 \pm 0.05^{\mathrm{Cb}}$ \\
4h & $190.69 \pm 0.02^{\mathrm{Bb}}$ & $209.98 \pm 0.04^{\mathrm{Ba}}$ & $91.37 \pm 0.03^{\mathrm{Cc}}$ & $196.08 \pm 0.06^{\mathrm{Bb}}$ \\
$12 \mathrm{~h}$ & $134.10 \pm 0.01^{\mathrm{Cc}}$ & $173.53 \pm 0.04^{\mathrm{Cb}}$ & $173.06 \pm 0.03^{\mathrm{Bb}}$ & $203.48 \pm 0.11^{\mathrm{Aa}}$ \\
$24 \mathrm{~h}$ & $110.05 \pm 0.03^{\mathrm{Cc}}$ & $202.40 \pm 0.11^{\mathrm{Ba}}$ & $186.88 \pm 0.07^{\mathrm{Bb}}$ & $183.77 \pm 0.23^{\mathrm{Bb}}$ \\
$48 \mathrm{~h}$ & $193.40 \pm 0.12^{\mathrm{Bb}}$ & $173.06 \pm 0.12^{\mathrm{Cc}}$ & $225.84 \pm 0.05^{\mathrm{Aa}}$ & $170.27 \pm 0.08 \mathrm{Cc}$ \\
$96 \mathrm{~h}$ & $201.16 \pm 0.06^{\mathrm{ABb}}$ & $197.90 \pm 0.02^{\mathrm{Bb}}$ & $231.11 \pm 0.02^{\mathrm{Aa}}$ & $213.57 \pm 0.01^{\mathrm{Aa}}$ \\
\hline
\end{tabular}

Note: in the table, different capital letters mean significant difference between different groups at different time points $(P<0.05)$, while different lowercase letters mean significant difference between different groups at the same time point $(P<0.05)$.

Effect of different taurine contents on MDA content in serum of Cynoglossus semilaevis

It can be seen from Table $\mathbf{1 1}$ that the MDA content is the lowest in the $0.5 \%$ group at $12 \mathrm{~h}$ after fishing stress, and the MDA content is the highest at $48 \mathrm{~h}$ after the fishing stress. The MDA content of the 4 groups was decreased from the higher level at $12 \mathrm{~h}$ after the fishing stress. In the $0 \%$ and $1 \%$ groups, the MDA content was similar to that before the stress, and remained stable at $12 \mathrm{~h}$ after the fishing stress. The MDA content of the $1.5 \%$ group was not significantly different at each time point. The content of MDA generally showed a trend of first increasing and then decreasing, and then increasing again and then decreasing, and the fluctuation was relatively large, and the fluctuation of $0.5 \%$ group was significant.

Table 11 Effect of different taurine contents on MDA content in serum of Cynoglossus semilaevis : $\mu \mathrm{mol} / \mathrm{g}$

\begin{tabular}{lllll}
\hline & $0 \%$ & $0.50 \%$ & $1 \%$ & $1.5 \%$ \\
\hline Before & $5.07 \pm 0.01^{\mathrm{Aa}}$ & $3.97 \pm 0.03^{\mathrm{Cb}}$ & $4.78 \pm 0.05^{\mathrm{Cb}}$ & $4.68 \pm 0.03^{\mathrm{Ab}}$ \\
Oh & $4.73 \pm 0.02^{\mathrm{Bc}}$ & $7.76 \pm 0.04^{\mathrm{Ba}}$ & $6.05 \pm 0.02^{\mathrm{Bb}}$ & $5.75 \pm 0.04^{\mathrm{Ab}}$ \\
$4 \mathrm{~h}$ & $6.05 \pm 0.02^{\mathrm{Ab}}$ & $7.81 \pm 0.04^{\mathrm{Ba}}$ & $6.44 \pm 0.05^{\mathrm{Bb}}$ & $6.58 \pm 0.09^{\mathrm{Ab}}$ \\
$12 \mathrm{~h}$ & $3.94 \pm 0.06^{\mathrm{Bab}}$ & $3.35 \pm 0.07^{\mathrm{Cb}}$ & $4.62 \pm 0.03^{\mathrm{Ca}}$ & $4.28 \pm 0.01^{\mathrm{Aa}}$ \\
$24 \mathrm{~h}$ & $3.45 \pm 0.04^{\mathrm{Bb}}$ & $7.51 \pm 0.08^{\mathrm{Ba}}$ & $7.37 \pm 0.12^{\mathrm{Aa}}$ & $4.13 \pm 0.11^{\mathrm{Ab}}$ \\
$48 \mathrm{~h}$ & $5.01 \pm 0.16^{\mathrm{Ab}}$ & $10.35 \pm 0.09^{\mathrm{Aa}}$ & $3.79 \pm 0.16^{\mathrm{CC}}$ & $3.74 \pm 0.07^{\mathrm{Ac}}$ \\
$96 \mathrm{~h}$ & $4.72 \pm 0.09^{\mathrm{Ba}}$ & $4.82 \pm 0.09^{\mathrm{Ca}}$ & $3.64 \pm 0.01^{\mathrm{Cb}}$ & $3.69 \pm 0.03^{\mathrm{Ab}}$ \\
\hline
\end{tabular}

Note: in the table, different capital letters mean significant difference between different groups at different time points $(P<0.05)$, while different lowercase letters mean significant difference between different groups at the same time point $(P<0.05)$.

3.12 Effect of different taurine contents on total antioxidant capacity of the Cynoglossus semilaevis

It can be seen from Table 12 that the total antioxidant capacity of the $1 \%$ group was the strongest at $0 \mathrm{~h}$ after the fishing stress, and the total antioxidant capacity was the worst in the $0.5 \%$ group at $48 \mathrm{~h}$ after the fishing stress. The total antioxidant capacity of each group remained almost at the same level at $4 \mathrm{~h}$ after the fishing stress. the $0.5 \%$ and $1.5 \%$ groups had an upward trend after $48 \mathrm{~h}$ of fishing stress, while the $0 \%$ and $1.5 \%$ groups showed a downward trend. At $12 \mathrm{~h}$ after the fishing stress, the 
total antioxidant capacity of each group greatly decreased, but remained stable afterwards. In general, the total antioxidant capacity of each group reached the highest level at $4 \mathrm{~h}$ after the fishing stress.

Table 12 Effect of different taurine contents on total antioxidant capacity of the Cynoglossus semilaevis: $\mu \mathrm{mol} / \mathrm{g}$

\begin{tabular}{lllll}
\hline & $0 \%$ & $0.50 \%$ & $1 \%$ & $1.5 \%$ \\
\hline Before & $62.04 \pm 0.04^{\mathrm{Ab}}$ & $66.35 \pm 0.07^{\mathrm{Ab}}$ & $83.46 \pm 0.01^{\mathrm{Aa}}$ & $71.20 \pm 0.03^{\mathrm{Aab}}$ \\
0h & $62.82 \pm 0.06^{\mathrm{Ac}}$ & $70.05 \pm 0.09^{\mathrm{Ab}}$ & $84.94 \pm 0.13^{\mathrm{Aa}}$ & $70.88 \pm 0.04^{\mathrm{Ab}}$ \\
$4 \mathrm{~h}$ & $70.88 \pm 0.03^{\mathrm{Ab}}$ & $73.84 \pm 0.08^{\mathrm{Ab}}$ & $81.48 \pm 0.15^{\mathrm{Aa}}$ & $78.60 \pm 0.04^{\mathrm{Aab}}$ \\
$12 \mathrm{~h}$ & $28.78 \pm 0.01^{\mathrm{Cb}}$ & $33.96 \pm 0.09^{\mathrm{BCb}}$ & $42.51 \pm 0.08^{\mathrm{Ba}}$ & $23.19 \pm 0.03^{\mathrm{Cc}}$ \\
$24 \mathrm{~h}$ & $28.45 \pm 0.01^{\mathrm{Cb}}$ & $45.14 \pm 0.04^{\mathrm{Ba}}$ & $24.09 \pm 0.03^{\mathrm{Cb}}$ & $29.87 \pm 0.02^{\mathrm{BCb}}$ \\
$48 \mathrm{~h}$ & $13.81 \pm 0.02^{\mathrm{Db}}$ & $12.91 \pm 0.04^{\mathrm{Db}}$ & $28.61 \pm 0.06^{\mathrm{Ca}}$ & $31.24 \pm 0.07^{\mathrm{Ba}}$ \\
$96 \mathrm{~h}$ & $45.63 \pm 0.07^{\mathrm{Ba}}$ & $28.45 \pm 0.02^{\mathrm{Cb}}$ & $20.47 \pm 0.06^{\mathrm{CC}}$ & $19.73 \pm 0.08^{\mathrm{CC}}$ \\
\hline
\end{tabular}

Note: in the table, different capital letters mean significant difference between different groups at different time points $(P<0.05)$, while different lowercase letters mean significant difference between different groups at the same time point $(P<0.05)$.

\section{Discussion}

Effects of different taurine on the growth of the Cynoglossus semilaevis

Taurine is a sulfur-containing amino acid that is closely related to the metabolism of cystine and cysteine. According to the current research, taurine is an indispensable substance for the healthy growth and development of animals. The intake of taurine in fish has a very positive effect on its early growth (Eranullall, 1998). As a kind of economic fish, Cynoglossus semilaevis is very economical. At present, there are many researches on Cynoglossus semilaevis, especially for the growth of Cynoglossus semilaevis feed additives. Growth indicators are an important indicator of feed performance. The results of this experiment showed that the $0.5 \%$ group had the highest body weight, the $0.5 \%$ group had the highest protein efficiency, the specific growth rate, and the bait efficiency was the lowest, which was not significantly different from other test groups. Studies have shown that when the content of taurine in the feed is $0 \%$ $0.5 \%$, the relative weight gain rate of the Cynoglossus semilaevis is gradually increased, which has a positive effect on feeding (Kim et al., 2003). Ordinary fishmeal contains a large number of plant-derived proteins, which have some defects. Plant-derived proteins contain more inhibitory growth factors and lack some amino acids. For example, soybean meal lacks methionine, corn gluten lacks lysine, and most importantly, most plants. The source proteins are all deficient in taurine (Francis et al., 2001). Studies on carnivorous rainbow trout, grass carp, cobia, and gums have shown that the addition of an appropriate amount of taurine to the feed promotes its growth (Park et al., 2001).

\section{Effects of different taurine levels on total protein of the Cynoglossus semilaevis}

Protein is an important component of all cells and tissues that make up fish. Protein is required for all important components of the body (Tsuji et al., 1979). The results of this experiment showed that the activities and feeding of the Cynoglossus semilaevis in each test group were normal. At $12 \mathrm{~h}$ after stress, the total protein content in the $0.5 \%$ group was significantly higher than that in the other groups $(P<0.05)$, and the protein levels in the $0.5 \%, 1 \%$, and $1.5 \%$ groups were significantly higher than those in the $0 \%$ group $(P<0.05)$. The highest value in the $1.5 \%$ group occurred $12 \mathrm{~h}$ after stress, and the highest value in the $0 \%$ group appeared $4 \mathrm{~h}$ after stress. There was no significant difference in protein levels between the $0.5 \%$ and $1 \%$ groups. It indicates that taurine has a protective effect on proteins and promotes the synthesis of proteins. The results that the physiological functions of taurine showed that taurine can promote the 
synthesis of proteins by regulating the trace elements in the body (Zhang $\mathrm{P} W$, et al.1997\& Luo Y W, et al.2013).

\section{Effects of different taurine levels on cholesterol in Cynoglossus semilaevis}

Cholesterol is widely present in animals, especially in brain and nerve tissue. Cholesterol is an indispensable substance in animal tissue cells. It is not only an important component of cell membrane, but also metabolized into bile acids and steroid hormones such as 7-dehydrocholesterol. Cholesterol is also an important indicator of clinical biochemical tests. Under normal circumstances, cholesterol synthesized by the body in the liver and taken from food will be converted into steroid hormones or become a component of the cell membrane, and the concentration of cholesterol in the blood will be kept constant (Zhang et al., 2014).

The results of this experiment showed that the cholesterol content in the $1 \%$ group was the highest in the $1 \%$ group after tracing stress, which was significantly higher than that in the other groups $(P<0.05)$. At other time points, the difference was not significant $(P>0.05)$. The cholesterol level in the $0.5 \%$ group was lower than that in the $0 \%$ group $(P<0.05)$, and the cholesterol level in the $1.5 \%$ group fluctuated greatly and was unstable. The study showed that taurine can reduce serum total cholesterol, on the one hand accelerate the clearance of cholesterol in the blood circulation, on the other hand, inhibit the release of cholesterol into the blood circulation, and promote the metabolism of cholesterol (Zhang et al., 2014). This is consistent with the results of this study, indicating that taurine can lower the cholesterol in the blood.

\section{Effects of different taurine levels on alanine aminotransferase in the Cynoglossus semilaevis}

Alanine aminotransferase (GPT) is an important aminotransferase widely present in mitochondria of animal cells and plays an important role in protein metabolism. Under normal circumstances, only a small amount of transaminase in animal tissues is released into the blood, and its activity is small. When the tissue is damaged or damaged, the transaminase in the cells is released into the blood in a large amount. Therefore, elevated blood GPT and GOT are important indicators of liver function impairment (Zhang et al., 2011).

The results of this experiment showed that the GPT in the 1\% group was significantly higher than that in the other groups at $12 \mathrm{~h}$ after the fishing stress, the difference was significant $(P<0.05)$; the difference between the $0 \%$ group and the $0.5 \%$ group was not significant $(P>0.05)$, and the other time points were different. The difference was not significant ( $P>0.05$ ). The GPT levels in the $0.5 \%$ group and the $0 \%$ group were roughly the same, the GPT level in the $1 \%$ group was significantly lower than that in the other three groups $(P<0.05)$, and there was a significant increase in the $12 \mathrm{~h}$ after stress $(P<0.05)$. The $1.5 \%$ group showed a stable trend, and there was no significant difference between the GPT levels and the $0 \%$ group at each time point $(P<0.05)$. It indicates that the fishing stress has a certain degree of damage to the liver, which will lead to a decrease in GPT activity and an increase in GPT content in the blood. The addition of taurine can inhibit the GPT content in the blood, thereby reducing the release of transaminase into the blood and reducing The degree of damage to the tissue by fishing stress indicates that taurine has a certain protective effect on liver function, which is consistent with the conclusion that it have an antagonistic effect on the free radical damage of liver tissue after exhaustive exercise in rats (Wei Y, et al.2002).

\section{Effects of different taurine levels on transaminase of Asparagus officinalis}

Aspartate aminotransferase (GOT) is an important indicator for detecting liver function in the clinic. When tissue lesions or damage, cell membrane permeability is enhanced, and even cells are ruptured, and intracellular transaminase is released into the blood in large amounts ( $\mathrm{Li}$ et al., 2008). It can be seen from Table 5 that at $12 \mathrm{~h}$ after the fishing stress, the GOT level in the $0 \%$ group was significantly higher than 0 . In the other test group $(P<0.05)$ group, $0.5 \%$ in the test group, the GOT level was significantly 
decreased at $96 \mathrm{~h}$ after the stress $(P<0.05)$, there was no significant difference at other time points $(P>0.05)$. The GOT levels in the $1 \%$ group and the $1.5 \%$ group were significantly increased at $4 \mathrm{~h}$ after stress $(P<0.05)$. It may be due to excessive addition of taurine and increased anti-stress effect, resulting in intolerance. the results of the study that taurine can significantly inhibit the increase of GOT content in blood are consistent ( $\mathrm{Li}$ et al., 2008). When the fishing stress causes damage to the tissue, taurine protects the tissue, thereby reducing the amount of transaminase in the blood.

\section{Effects of different taurine levels on nitric oxide in Cynoglossus semilaevis}

Nitric oxide is an indispensable regulator of the immune system's function. It acts on blood vessels, acts as a relaxing blood vessel, acts on the immune system, and acts as a bridge in the central nervous system, the role of neurotransmitters (Fan et al., 2009). The experimental study showed that before the fishing stress, the content of nitric oxide in the $1.5 \%$ group was the highest, and was significantly different from other test groups $(P<0.05)$. At $24 \mathrm{~h}$ after the fishing stress, the nitric oxide content in the $0 \%$ group was significantly higher than other tests. The group $(P<0.05)$, the difference between the other test groups was not significant $(P>0.05)$. The average level of nitric oxide in each group increased significantly at $96 \mathrm{~h}$ after stress, which may increase the anti-stress effect of the body due to the fishing stress and the addition of taurine.

\section{Effects of different taurine levels on lysozyme of the Cynoglossus semilaevis}

Lysozyme is an important component of the fish's non-specific immune system. It is the material basis for phagocytic sterilization, destroying and eliminating pathogens such as bacteria invading the body, thus taking on the body's defense function (Qiu et al., 2008). It can be seen from Table7 that the lysozyme content in the $1.5 \%$ group was significantly higher than that in the other groups $(P<0.05) 4 \mathrm{~h}$ after the fishing stress; for the $0 \%$ group, the lysozyme level decreased significantly $4 \mathrm{~h}$ after the stress $(P<0.05)$. $<0.05)$, then return to the pre-operational level. The study that the effect of taurine on the non-specific immune system of carp, the results showed that the addition of $0.1 \%$ taurine to the feed can significantly improve the lysozyme activity of the squid serum (Qiu et al., 2008; Ling et al., 2012). Similar to the results of this test. The $0.5 \%$ group has the same trend as the $0 \%$ group. The values of lysozyme levels in the $1 \%$ group and the $1.5 \%$ group fluctuated greatly.

\section{Effect of different taurine levels on glucose in Cynoglossus semilaevis}

Glucose is the most widely distributed and most important monosaccharide in nature. Glucose plays an important role in the biological field and is the energy source and metabolic intermediate of living cells. Glucose can promote the detoxification function of the liver, has a protective effect on the liver, and is an important energygiving substance of the organism (Yang et al., 2012). The results of this experiment showed that the blood glucose level in the $1.5 \%$ group was significantly higher than that in the other groups before the fishing stress $(P<0.05)$. The peak of glucose level in the $0.5 \%$ group appeared $48 \mathrm{~h}$ after stress. The overall trend of the $1 \%$ group and the $1.5 \%$ group was stable. It indicated that taurine may have an effect on the glucose content before the fishing stress. After the fishing stress, taurine may have the effect of helping the body to resist stress.

\section{Effects of different taurine contents on glutathionease activity of the Cynoglossus semilaevis}

Glutathione is a natural tripeptide composed of glutamic acid, glycine, and cysteine. It is a small molecule antioxidant that is ubiquitous in eukaryotic cells. It plays a key role in eliminating oxygen free radicals in the body. It is the key. The biological mechanism of the antioxidant system of the enzyme, the liver content of each animal is very rich, can be used for important test indicators of stress test, and is also an important factor to measure the body's antioxidant capacity (Chen, 2006). Glutathione in 
fish is used to maintain the balance of antioxidant levels in the body and is an indicator of the antioxidant capacity of fish.

Glutathione is a type of peroxidase that is a decomposing enzyme that toxic compounds catalyze as non-toxic compounds. The results of this experiment showed that the glutathione peroxidase activity was highest in the $1 \%$ group, and the glutathione peroxidase activity in the $1.5 \%$ group also reached a higher level after the fishing stress. The content of taurine increased, and the activity of glutathione peroxidase increased first and then decreased, and then gradually stabilized. It shows that the increase of taurine content in the feed can increase the activity of glutathione peroxidase to a certain extent, improve the liver ability of the fish, and make the fish grow healthily, but there is some fluctuation, indicating the sulfur in the feed. The acid content may have little effect on glutathione peroxidase activity in the liver. This may be related to the feeding habits of fish and the adaptability to nutrients.

\section{Effect of different taurine contents on the activity of total superoxide dismutase in the Cynoglossus semilaevis}

Total superoxide dismutase (T-SOD), also known as hepatic protein, is an active protease derived from living organisms, which contains a high content of various tissues containing metal elements and is capable of freeing superoxide anion. The elimination of the base allows the damaged cell membrane to be repaired, preventing inflammation, tumors and autoimmune diseases, thereby delaying aging (Li et al., 1993).

The experiment showed that the SOD activity in the 1\% group was the highest at $96 \mathrm{~h}$ after the fishing stress, and the activity of SOD was lower than that in the other groups after $4 \mathrm{~h}$ of the fishing stress, indicating that the free radicals in the body were produced at a higher rate than the body at $4 \mathrm{~h}$ after the stress. The rate of self-clearing free radicals breaks the equilibrium state of free radical scavenging and production, leading to a gradual decline in the effect of eliminating free radicals and a decrease in the activity of SOD. As the time of fishing stresses, it shows a trend of decreasing first and then rising. With the increase of taurine content in the feed, the difference between the groups was not significant, but it could still increase the SOD activity in the body, indicating that increasing the content of taurine in the feed can increase the SOD activity in the fish.

Effect of different taurine content on the content of malondialdehyde in Cynoglossus semilaevis

Malondialdehyde (MDA) is a peroxide formed by the reaction of some macromolecules such as biofilm phospholipids, reactive oxygen species, membrane receptors and enzymes in living organisms. It is a kind of metabolism derived from lipid peroxidation. The product can be used as an important indicator of the degree of cellular oxidation damage (Chen, 2010).

The results of this study showed that the $0.5 \%$ group had the lowest malondialdehyde content at $12 \mathrm{~h}$ after stress. At $12 \mathrm{~h}$ after the fishing stress, the MDA content of the 4 groups dropped from the higher value to the pre-stress level. The content of malondialdehyde increased first and then decreased with the increase of fishing stress time, and the content of malondialdehyde increased. The reason may be that a large number of free radicals were generated, and the biofilm containing polyunsaturated fatty acids was destroyed, causing lipid peroxidation. The greater volatility may indicate that the taurine in the feed has a certain stimulating effect on the malondialdehyde content in the Cynoglossus semilaevis.

\section{Effect of different taurine contents on total antioxidant capacity of the Cynoglossus semilaevis}

The total antioxidant capacity (T-AOC) is a comprehensive indicator of whether the body's antioxidant system is normal, and its content can reflect the ability of the organism's antioxidant enzyme system and non-enzymatic system to face external stimulation instead of compensation and the body's free radical metabolism (Zhang et al., 
2014). The increase in total antioxidant capacity has a very positive effect on delaying aging(Zhao et al., 2015).

The results of this study showed that the total antioxidant capacity of the $1.0 \%$ group was the strongest at $0 \mathrm{~h}$ after the fishing stress. At $4 \mathrm{~h}$ after the fishing stress, the total antioxidant capacity of each group remained at a high level. At $12 \mathrm{~h}$ after the fishing stress, the total antioxidant capacity of each group decreased significantly. Overall, it can show a tendency to decrease rapidly after increasing first. With the increase of taurine content in the feed, the total antioxidant capacity of the Cynoglossus semilaevis has slightly increased, but the content is too high, which will inhibit the total antioxidant capacity, indicating that the taurine in the feed is properly increased. The content can increase the Cynoglossus semilaevis to increase the total antioxidant capacity.

\section{Conclusion}

In this experiment, feeds with different levels of taurine were fed to the Cynoglossus semilaevis and fed for 28 days. Research indicates:

(1) Feeding a feed with a taurine content of $0.5 \%$, the Cynoglossus semilaevis grows better, and the feed with a taurine content of $1.5 \%$ has a certain inhibitory effect on the growth of the Cynoglossus semilaevis.

Feeding the feed with taurine content of $0.5 \%$ had better inhibition effect on cholesterol and GOT of Cynoglossus semilaevis after fishing stress; the anti-stress effect on lysozyme and protein was obvious.

(2) In the group with $1.5 \%$ taurine, the GPT level was stable and the anti-stress effect was better.

(3) The blood biochemical indicators of the semi-smoothed scorpion fed with large volatility indicate that the biochemical indicators of the Cynoglossus semilaevis are unstable under the influence of fishing stress.

(4) $0.5 \%, 1 \%$ group glutathione peroxidase activity, total superoxide dismutase activity and total antioxidant capacity, feeding $0.5 \%$ taurine feed, fish MDA content is low. Feeding a feed with a taurine content of $1.5 \%$ had little effect on the antioxidant indices of the Cynoglossus semilaevis.

(5) The antioxidant properties of the Cynoglossus semilaevis have some obvious changes after the fishing stress, but they often have large fluctuations, indicating that the antioxidant system is unstable.

In summary, combined with the research results and the cost of taurine, the feed with $0.5 \%$ taurine content has better response to the fishing stress and the economic benefit is greater.

\section{Acknowledgments}

Supported by China Agriculture Research System (CARS-47), Tianjin University Innovation Team Training program modern aquaculture ecological health breeding (TD13-5089), Tianjin Science and Technology Program Project (14ZCZDSY00053), Tianjin Aquatic Modern Agricultural Industry Technology System Innovation Team (ITTFRS2017004), Tianjin Aquatic Modern Agricultural Industry Technology System Innovation Team (ITTFRS2019049).

\section{References}

Chen D.H. 2006. Greenhouse culture experiment of freshwater grouper . Aquatic science and technology information,33:15-16. (in Chinese with English abstract)

Chen S.L., Du.M., Yang J.F. 2010. Establishment, growth and disease resistance of half-smooth tongue sole family. Chinese journal of fisheries, 34:1780-1794. (in Chinese with English abstract)

Eranullall J.A.K. 1998. Growth rate feed conversion and body composition of carbohydrate. Aquaculture, 29:84-97.

Fan J.H., Liu K., Liu B.L. 2009. Regulation of NO in inflammation and immune response. China Med,28:163. (in Chinese with English abstract)

Francis G., Makkar H.P.S., Becker K. 2001. Antinutritional factors present in the plant - derived alternate fishfeed Ingredients and their effects in fish. Journal of Aquaculture, 199:197-227. (in Chinese with English abstract)

Kim S.K., Takeuchi T., Yokoyama M. 2003. Effect of dietary supplementation with taurine, 
Balanine and GABA on the growth of juvenile and fingerling Japanese flounder Paralichthys olivaceu s. Fisheries Science, 69:242-248.

Li Y., Ru S.G. 2008. Effects of long-effect phosphorus on transaminase activity of glutamine and glutamate in liver and plasma of goldfish. Chinese journal of safety and environment,08:9-12. (in Chinese with English abstract)

Ling Y. 2012. Effects of taurine on the activity of non-specific immune digestive enzymes and antioxidant capacity of Hoplobatrachu of tiger frog. Zhejiang normal university. (in Chinese with English abstract)

Liu J.L., Li Q.Y. 2011. Comparative study on lysozyme activity of four cultured fish. Tianjin agricultural sciences,17:42-44. (in Chinese with English abstract)

Luo Y.W., Ai Q.H., Ma K.S. 2013. Effects of taurine and cholesterol in feed on growth, body composition and blood parameters of juncao fish. Journal of ocean university of China,43:31-36. (in Chinese with English abstract)

Park G.S., Takeuchi T, Seikai T. 2001. The effects of dietary taurine on growth and taurine Levels in whole body of flounder Japanese flounder olivaceus. Nippon Suisan Gakkaishi, 67: 238243.

Qiu X.C., Zhao H.X., Wang Y.J. 2008. Effects of taurine on non-specific immunity and antioxidant capacity of carp. Journal of Shanghai fisheries university,17:25-31. (in Chinese with English abstract)

https://doi.org/10.1093/nar/gks1219

Tsuji K., Seki T., Iwao H. 1979. Cholesterol-lowering effects of taurine and sulfur - containing amino acids in serum and liver of rats. Journal of sulfur - containing amino acids, 2:14 3-145.

Wang H.W., Ye J.G., Chen J.C. 2013.Taurine: Effect in Fish Nutrition and Application in Fish Feed. Chinese Journal of Animal Nutrition,25:1418-1428.

https://10.3969/j.issn.1006-267x.2013.07.004

Wei Y., Wang X., Li L.M. 2002. Effects of taurine on free radical damage of liver tissue after exercise in rats. Chinese journal of sports medicine,21:213-214. (in Chinese with English abstract)

Yang F.Y.2012. Effects of different protein source combinations and glucose levels on production performance and blood biochemical indexes of weaned piglets. Henan agricultural university.

Zhang P.W., Yang Z.Y. 1997. Physiological functions and nutritional effects of taurine. Chinese journal of food health,5:38-42. (in Chinese with English abstract)

Zhang S., Guo J.X., Chen W. 2014.Research progress of taurine on cholesterol metabolism. Journal of food safety and quality inspection, 5:85-89.

Zhang X., Cheng F.S. 2011.Effects of GPA on GOT and GPT in serum and liver tissue after liver injury in mice. Chinese journal of veterinary medicine, 13:17-19. (in Chinese with English abstract) Zhao M., Liang M.Q., Zheng K.K. 2015. Effects of taurine on reproductive capacity and quality of larvae of half-smooth tongue sole. Advances in fishery science,36:101-108. (in Chinese with English abstract) 